\title{
DRUG DISCOVERY AGAINST COVID-19 FROM INDIAN MEDICINAL PLANTS - COMPUTATIONAL APPROACH
}

\author{
Satyam Sangeet \\ Department of Biological Science \& Engineering \\ Maulana Azad National Institute of Technology, Bhopal, \\ Madhya Pradesh, India
}

\begin{abstract}
Coronavirus pandemic has caused an enormous misfortune for the worldwide economy just as worldwide wellbeing. Such cases show us the need to create vaccines against novel infections that continually develops with nature. Currently more than 200 potential candidate vaccines are in the preliminary stages, but not many of them has given some certain outcomes. The $3 \mathrm{CL}^{\text {pro }}$ sequence has a major involvement in the replication of the viral genome. Consequently, it goes about as an expected site for the anti COVID-19 medications. The current examination centers around screening the Indian medicinal plants and their heavy metal nanoparticle conjugates for their capacity to go about as a characteristic inhibitor for the infection.
\end{abstract}

Keywords- Iron Nanoparticles (FeNPs), Gold Nanoparticles (AuNPs), Zinc Nanoparticles (ZnNPs), Reverse Transcriptase Polymerase Chain Reaction (RTPCR), Atomic Contact Energy (ACE)

\section{INTRODUCTION}

In 2019 a new strain of infection was distinguished that caused deadly respiratory ailment [Xu and Chen 2020]. WHO initially classified the virus as 2019 novel coronavirus (2019-nCoV) [Ji 2020]. Later, in January 2020 the primary genome sequence of the virus became accessible that provided an upper edge to the researchers to build a RT-PCR to distinguish the malady in affected patients [Ma et al. 2020]. As of $30^{\text {th }}$ August 2020, according to WHO overall in excess of 24 million affirmed cases have been accounted for with in excess of 8 lakh deaths spreading across 216 nations. Recent investigations have proposed that Angiotensin Receptor 1 (ATR1) may prove advantageous for the individuals who get tainted with COVID-19 and face pneumonia like indications. Phadke and Saunik [Phadke and Saunik 2020] likewise proposed the conceivable utilization of ATR1 blockers to treat patients with COVID-19. Considering the way that these investigations are focusing on the likely utilization of ATR1 inhibitors comes from the perceptions that Angiotensin Converting Enzyme 2 (ACE2) acts as a main site for the docking of spike protein of SARS-CoV-2.

\author{
Arshad Khan \\ Department of Biological Science \& Engineering \\ Maulana Azad National Institute of Technology, Bhopal, \\ Madhya Pradesh, India
}

There are various literatures describing the taxonomy of coronavirus and categorizing it in the Coronaviridae family and Coronavirinae sub-family [Chen et al. 2020; Hu et al. 2018]. Despite the fact that the Sars-CoV-2 is ordered in betaCoronavirus group, it is unique in relation to the MERS-CoV and SARS-CoV. Ongoing investigations have demonstrated that the SARS-CoV-2 shares a limited nucleotide identity and similarity with the SARS-CoV [Tao et al. 2020; Zhou et al. 2020]. The viruses placed in the beta-Coronavirus group usually generates $800 \mathrm{kDa}$ polypeptide when their genome transcription occurs. The polypeptide generated is then cleaved in order to produce different proteins. The proteolytic disintegration of the polypeptide is governed by 3Chymotrypsin-like protease $\left(3 \mathrm{CL}^{\mathrm{pro}}\right)$ and Papain-like protease $\left(\mathrm{PL}^{\mathrm{pro}}\right)$. $3 \mathrm{CL}^{\mathrm{pro}}$ is responsible for the segmentation of the polypeptide at 11 distinct places so that the viral proteins can be generated [Anand et al. 2003]. Homology modelling have revealed that $3 \mathrm{CL}^{\text {pro }}$ has highly conserved sequence. Several inhibitors of $3 \mathrm{CL}^{\text {pro }}$ have been discovered in past via highthroughput screening and rational drug design [Kumar et al. 2013; Kuo et al. 2015]. Hence, it is fair to consider that it can potentially act as an inhibitor for the coronavirus [Needle et al. 2015].

Tahir and group [Tahir et al. 2020] have exhibited a 3D homology model of the 3CL pro sequence (PMDB ID: PM0082635) and screened it against the Chinese medicinal plants.

The worldwide pandemic circumstance has impelled various nations to act quickly and find a potential fix as an antibody against this fatal infection. At present in excess of 200 active candidate vaccines are in progress against the infection [Lurie et al. 2020]. The outcomes from two vaccine trials are accounted for, one from AstraZeneca upheld Jenner Institute at Oxford University [Folegatti et al. 2020] and the other from CanSino Biologics from Wuhan, China [Zhu et al. 2020]. Both of these vaccine trials have indicated positive outcomes in there $1 / 2$ stage. Since the populaces scale was low and ethnic diversity was low [Bar-zeev and Moss 2020], we are still in a race to locate a superior fix. One potential approach to attempt to do this is to concentrate on the characteristic accessibility of the therapeutic components found in the nature. Indian 


\section{International Journal of Engineering Applied Sciences and Technology, 2020 Vol. 5, Issue 6, ISSN No. 2455-2143, Pages 324-330 \\ Published Online October 2020 in IJEAST (http://www.ijeast.com)}

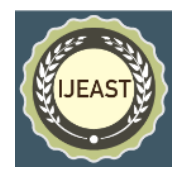

medicinal plants, particularly those that are utilized straightforwardly in a palatable manner has pulled in much consideration due to the naturally occurring bioactive components present in them.

Biosynthesized metal nanoparticles have shown significant antiviral activity [Kuppuswamy et al. 2016]. Silver oxide and gold nanoparticles synthesized using Oscillatoria sp. and $S$. platensis, respectively have inhibited the growth and replication of Herpes Simplex (HSV-1) [El-Sheek et al. 2020]. The bio-synthesized Silver nanoparticles from the plant extract of Andrographis paniculata and Tinospora cordifolia demonstrated a high antiviral behavior when screened against Chikungunya virus [Sharma et al. 2019]. Thus, there is a need to synthesize heavy metal nanoparticles to explore their aniviral properties.

Thus, the present study focusses on the screening of Indian medicinal plants and their heavy metal nanoparticle conjugates (Iron, Gold and Zinc) against the $3 \mathrm{CL}^{\text {pro }}$ sequence of Sars$\mathrm{CoV}-2$ virus in order to explore natural bioactive compounds having a potential to act as a natural inhibitor against the virus.

\section{MATERIALS AND METHOD}

\section{A. Data Collection}

A comprehensive phytochemical database was created containing major phytochemicals obtained from the Indian medicinal plants. While curating the data, we only targeted those Indian medicinal plants that are commonly used in the spices. These phytochemicals as well as their nanoparticle conjugates (Iron, Gold and Zinc) were screened against the $3 \mathrm{CL}^{\text {pro }}$ sequence of viral structure (PMDB ID: PM0082635) submitted by [Tahir et al. 2020].

\section{B. Molecular Docking Studies}

PatchDock online server was utilized for the docking studies. The structure of phytochemicals and heavy metals were downloaded from PubChem database. The details of the phytochemicals are given in Table 1 . The $3 C^{\text {pro viral }}$ structure was download from PMDB database (PMDB ID: PM0082635). The nanoparticle conjugates of the respective phytochemicals were made using ChemOffice [ChemOffice 2002]. Ligands were energy minimized using Chem3D and the protein was energy minimized using Chimera [UCSF Chimera 2004]. The protein file was made clear by deleting the native ligand and the water molecules. As suggested by the tool, the RMSD value was fixed at $<4 \AA$. The result obtained were then visualized in Discovery studio.

\section{RESULT AND DisCUSSION}

The molecular docking was carried out between the SARCoV-2 3CL pro and the major phytochemicals of the medicinal plants and their nanoparticles. The GC-MS data of the medicinal plants were collected and the major phytochemicals were identified. We gathered 14 medicinal plants with the possibility of their phytochemicals to act as a natural inhibitor against the SARS-CoV-2 $3 \mathrm{CL}^{\text {pro }}$. We made their respective nanoparticles with heavy metals such as Iron (FeNPs), Gold (AuNPs) and Zinc (ZnNPs). Out of the 14 plants, 5 FeNPs conjugate of the plants, 2 AuNPs conjugate of the plants and 2 ZnNPs conjugate of the plants showed the desired results. The results are shown in Table 2.

\section{A. Iron Nanoparticles}

The major phytochemicals of the 15 medicinal plants and their iron nanoparticle conjugates were docked against SARS-CoV$23 \mathrm{CL}^{\text {pro }}$. Out of the 15 medicinal plants only 5 of them showed the desired results against the viral structure. The docking of FeNP with SARS-CoV-2 3CL pro showed an unfavorable binding with Arg298 (figure 1a). Eugenol was identified as the major phytochemical in Pan (Piper betel) [Madhumita et al. 2019] and Clove (Syzygium aromaticum) [Srivastava et al. 2005]. The docking of eugenol with SARSCoV-2 3CL ${ }^{\text {pro }}$ showed hydrophobic interaction with Met165 and Cys 145 with a docking score of 3,132 and an ACE of $126.38 \mathrm{kcal} / \mathrm{mol}$ (figure 1b). On the other hand, the docking of Eugenol conjugated with Iron (Eugenol-FeNP) showed a pidonor hydrogen bonding with the His41 and hydrophobic interaction with Cys145 and His163 with a docking score of 3,528 and ACE of $-98.25 \mathrm{kcal} / \mathrm{mol}$ which was higher than eugenol alone (figure 1c). Thymol was identified as the major phytochemical found in Ajwain (Trachyspermum ammi L) [Dhaiwal et al. 2017]. Docking analysis of thymol with SARSCoV-2 3CL ${ }^{\text {pro }}$ showed hydrophobic interactions with His41, Cys145, His163, Met165 and Met49 with a docking score of 3,082 and ACE of $-126.41 \mathrm{kcal} / \mathrm{mol}$ (figure 1d). The docking of thymol conjugated with iron (Thymol-FeNP) showed carbon hydrogen bonding with Asn142 and hydrophobic interactions with Met49, Cys145, Met165 and His41 with a docking score of 3,254 and ACE of $-48.84 \mathrm{kcal} / \mathrm{mol}$ which was higher than thymol alone. Also, the iron ion showed metal acceptor bonding with Leu141 (figure 1e). Carvone was identified as the major phytochemical in Corn Mint (Mentha arvensis) [Balasubramanian et al. 2016]. The docking of carvone with the viral structure showed hydrophobic interactions with Met6, Arg298 and Phe8 and a restricted binding with Ser123 with a docking score of 3,100 and an ACE of $-120.57 \mathrm{kcal} / \mathrm{mol}$ (figure 1f). The docking of carvone conjugated with iron (Carvone-FeNP) showed carbon hydrogen bonding with Asn 142 and hydrophobic interactions with Met49, Met165, Cys145 and His41 with a docking score of 3,356 and an ACE of $-64.93 \mathrm{kcal} / \mathrm{mol}$ which was more than carvone alone. The iron ion also showed metal acceptor bonding with Leu141 and Ser144 (figure 1g). Methyl isoeugenol was identified as the major phytochemical in Tulsi (Ocimum sanctum) [Balasubramanian et al. 2014]. The docking of methyl isoeugenol with SARS-CoV-2 3CL pro showed hydrophobic interactions with Cys145 and His163 and a restricted interaction with Glu166 with a docking score of 3,440 and an ACE of $-125.25 \mathrm{kcal} / \mathrm{mol}$ (figure $1 \mathrm{~h}$ ). The 


\section{International Journal of Engineering Applied Sciences and Technology, 2020 \\ Vol. 5, Issue 6, ISSN No. 2455-2143, Pages 324-330 \\ Published Online October 2020 in IJEAST (http://www.ijeast.com)}

docking of methyl isoeugenol conjugated with iron (Methyl isoeugenol-FeNP) showed carbo hydrogen bonding with Met165 and hydrophobic interactions with Cys145, Met49 and His41 with a docking score of 3,584 and an ACE of -103.34 $\mathrm{kcal} / \mathrm{mol}$ which was more than methyl isoeugenol alone (figure 1i). Thus, this study suggests that the iron conjugates of the respective phytochemicals showed better binding affinity than their respective phytochemical part. Thus, there is a possibility that the nanoparticle conjugates of the respective phytochemicals might prove beneficial in the form of natural inhibitor against SARS-CoV-2 3CL pro<smiles>CCCCC(C)C</smiles>

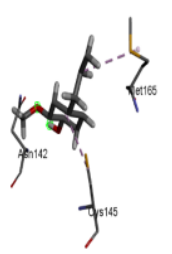

(a)

(b)

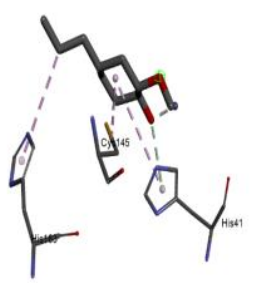

(c)

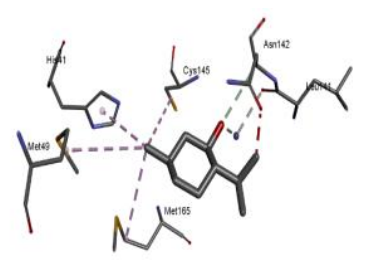

(e)

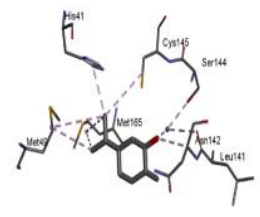

(g)

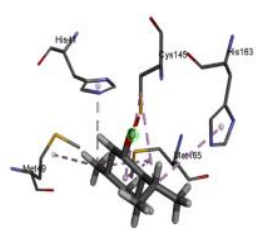

(d)

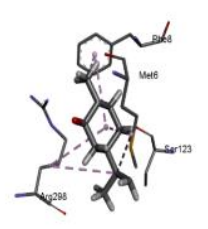

(f)

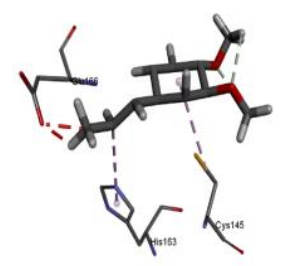

(i)

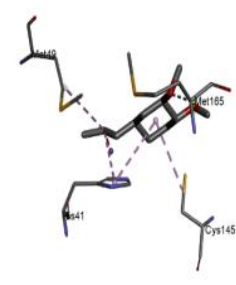

(i)

Fig. 1. Docking analysis of SARS-CoV-2 $3 \mathrm{CL}^{\text {pro }}$ with (a) FeNP (b) Eugenol (c) Eugenol-FeNP (d) Thymol (e) Thymol-FeNP (f) Carvone (g) Carvone-FeNP (h) Methylisoeugenol (i) Methylisoeugenol-FeNP

\section{A. Gold Nanoparticles}

The phytochemicals of 15 medicinal plants and their gold nanoparticle (AuNPs) conjugate were docked with SARSCoV-2 3CL pro. The docking of AuNP with SARS-CoV-2 $3 \mathrm{CL}^{\text {pro }}$ showed a metal acceptor binding with Met6 (figure 2a). Out of 15 plants only 2 showed desire results. Eugenol, the major phytochemical of Pan (Piper betel) [Madhumita et al. 2019] and Clove (Syzygium aromaticum) [Srivastava et al. 2005] when docked with SARS-CoV-2 3CL pro showed hydrophobic interactions with Cys145 and Met165 and a restricted interaction with Asn 142 with a docking score of 3,132 and an ACE of $-126.38 \mathrm{kcal} / \mathrm{mol}$ (figure $2 \mathrm{~b}$ ). On the other had the docking of eugenol conjugated gold nanoparticle (Eugenol-AuNP) showed hydrogen bonding with Glu166, carbon hydrogen bonding with Phe140 and hydrophobic interactions with Cys145, Leu27, and His41 with a docking score of 3,332 and an ACE of $-105.83 \mathrm{kcal} / \mathrm{mol}$ which was more than eugenol alone (figure $2 \mathrm{c}$ ). The gold ion showed metal acceptor bonding with Glu166. Thus, this study suggests that the gold conjugate of eugenol (Eugenol-AuNP) shows better binding than eugenol alone and can possibly act as a natural inhibitor for the viral structure.

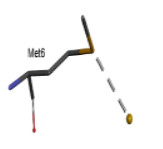

(a)

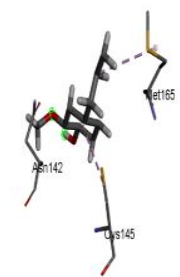

(b) 


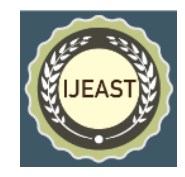

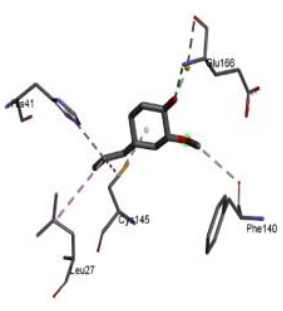

(c)

Fig. 2. Docking analysis of SARS-CoV-2 $3 C^{\text {pro }}$ with (a) AuNP (b) Eugenol (c) Eugenol-AuNP

\section{B. Zinc Nanoparticles}

Out of 15 medicinal plants, only 2 of them showed the desired results. The docking of ZnNPs with SARS-CoV-2 3CL pro showed a metal acceptor binding with Met6 and a restricted binding with $\operatorname{Arg} 298$ (figure 3a). Carvone was identified as the major phytochemical present in Corn Mint [Balasubramanian et al. 2016]. The docking of carvone with SARS-CoV-2 3CL pro showed hydrophobic interactions with Met6, Arg298 and Phe8 along with a restricted interaction with Ser123 with a docking score of 3,100 and an ACE of $120.57 \mathrm{kcal} / \mathrm{mol}$ (figure $3 \mathrm{~b}$ ). The docking of zinc conjugate of carvone (Carvone-ZnNPs) showed hydrogen bonding with His41, His164 and Met165. It also showed hydrophobic interactions with Met165, Met49, Cys145 and His163 with a docking score of 3,246 and an ACE of $-125.18 \mathrm{kcal} / \mathrm{mol}$ which was more than carvone alone (figure $3 \mathrm{c}$ ). The zinc ion of Carvone-ZnNPs also showed metal acceptor interaction with His41. Linalyl acetate was identified as the major phytochemical of Lavender [Negi et al. 2015]. Docking of Linalyl acetate with SARS-CoV-2 3CL pro showed hydrophobic interactions with Met49, Cys145, His41 and His163 with a docking score of 3,850 and an ACE of $-113.34 \mathrm{kcal} / \mathrm{mol}$ (figure $3 \mathrm{~d}$ ). The zinc conjugate of Linalyl acetate (Linalyl acetate-ZnNPs) showed hydrogen bonding with Cys145 and His163. It also showed hydrophobic interactions with Cys145, Met49, His41 and His163 with a docking score of 3,864 and an ACE of $-130.30 \mathrm{kcal} / \mathrm{mol}$ (figure 3e) which was lightly more than Linalyl acetate alone. The zinc ion also showed an electrostatic attractive interaction with Glu166. The zinc conjugates of carvone (Carvone-ZnNPs) and Linalyl acetate (Linalyl acetate-ZnNPs) showed better binding than their phytochemical counterpart. The nanoparticles conjugates might have a possibility to act as a natural inhibitor against SARS-CoV-2 3CL ${ }^{\text {pro }}$.

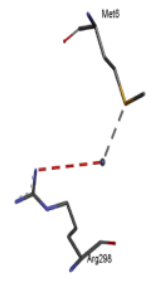

(a)

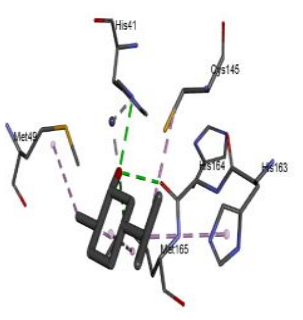

(c)

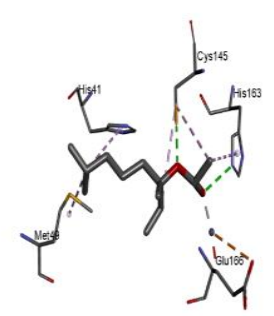

(e)

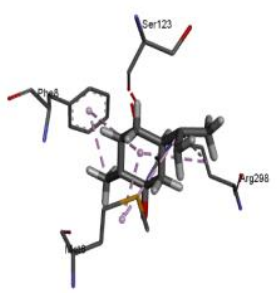

(b)

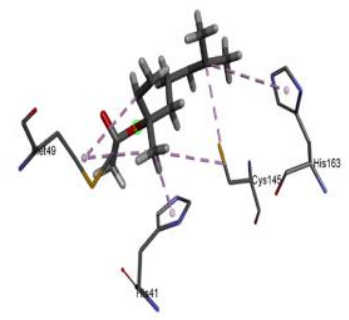

(d)
Fig. 3. Docking Analysis of SARS-CoV-2 3CL pro with (a) ZnNP (b) Carvone (c) Carvone-ZnNPs (d) Linalyl acetate (e) Linalyl actetateZnNPs

Table -1 Plants and their respective phytochemicals with PubChem CID

\begin{tabular}{|c|c|c|}
\hline Plants & Phytochemicals \\
$\begin{array}{c}\text { Ajwain } \\
\text { Trachyspermum } \\
\text { ammi L. })\end{array}$ & $\begin{array}{c}\text { Thymol [Dhaiwal } \\
\text { et al. 2017] }\end{array}$ & PubChem CID \\
\hline $\begin{array}{c}\text { Aloe vera } \text { (Aloe } \\
\text { vera } \text { L) }\end{array}$ & $\begin{array}{c}\text { Hexadecanoic } \\
\text { acid [Bawankar et } \\
\text { al. 2012] }\end{array}$ & 9899 \\
\hline $\begin{array}{c}\text { Cinnamon } \\
\text { (Cinnamomum } \\
\text { burmanii) }\end{array}$ & $\begin{array}{c}\text { Trans- } \\
\text { cinnamaldehyde } \\
\text { [Anshory and } \\
\text { Nugraha 2017] }\end{array}$ & 637511 \\
\hline $\begin{array}{c}\text { Clove (Syzygium } \\
\text { aromaticum })\end{array}$ & $\begin{array}{c}\text { Eugenol } \\
\text { [Srivastava et al. } \\
\text { 2005] }\end{array}$ & 3314 \\
\hline $\begin{array}{c}\text { Coriander } \\
\text { Coriandrum }\end{array}$ & $\begin{array}{c}\text { Geranyl acetate } \\
\text { [Pande et el. }\end{array}$ & 1549026 \\
\hline
\end{tabular}


International Journal of Engineering Applied Sciences and Technology, 2020

Vol. 5, Issue 6, ISSN No. 2455-2143, Pages 324-330

Published Online October 2020 in IJEAST (http://www.ijeast.com)

\begin{tabular}{|c|c|c|}
\hline sativum $\mathrm{L})$ & $2010]$ & \\
\hline $\begin{array}{c}\text { Corn Mint } \\
\text { (Mentha arvensis) }\end{array}$ & $\begin{array}{c}\text { Carvone } \\
\text { [Balasubramanian } \\
\text { et al. 2016] }\end{array}$ & 7439 \\
\hline $\begin{array}{c}\text { Fenugreek } \\
\text { (Trigonella } \\
\text { foenum-graecum) }\end{array}$ & $\begin{array}{c}\text { Cholestan-3-ol } \\
\text { [Kumaravel et al. } \\
\text { 2017] }\end{array}$ & 10992748 \\
\hline $\begin{array}{l}\text { Ginger (Zingiber } \\
\text { officinale) }\end{array}$ & $\begin{array}{c}\text { Zingiberene } \\
\text { [Taylor et al. } \\
\text { 2013] }\end{array}$ & 92776 \\
\hline $\begin{array}{l}\text { Henna (Lawsonia } \\
\text { inermis L) }\end{array}$ & $\begin{array}{c}\text { Acetic acid } \\
\text { [Mengoni et al. } \\
\text { 2015] }\end{array}$ & 176 \\
\hline $\begin{array}{c}\text { Lavender } \\
\text { (Lavandula } \\
\text { angustifolia) }\end{array}$ & $\begin{array}{c}\text { Linalyl acetate } \\
\text { [Negi et al. 2015] }\end{array}$ & 8294 \\
\hline $\begin{array}{l}\text { Lemongrass } \\
\text { (Cymbopogon } \\
\text { citratus) }\end{array}$ & $\begin{array}{c}\text { Citral [Ali et al. } \\
\text { 2017] }\end{array}$ & 638011 \\
\hline Pan (Piper betel) & $\begin{array}{c}\text { Eugenol } \\
\text { [Madhumita et al. } \\
\text { 2019] }\end{array}$ & 3314 \\
\hline $\begin{array}{l}\text { Tulsi }(\text { Ocimum } \\
\text { sanctum })\end{array}$ & $\begin{array}{c}\text { Methyl } \\
\text { isoeugenol } \\
\text { [Balasubramanian } \\
\text { et al. 2014] }\end{array}$ & 637776 \\
\hline $\begin{array}{c}\text { Turmeric } \\
\text { (Curcuma longa) }\end{array}$ & $\begin{array}{c}\text { Curcumin } \\
\text { [Tennyson et al. } \\
\text { 2019] }\end{array}$ & 969516 \\
\hline
\end{tabular}

\begin{tabular}{|c|c|c|c|}
\hline $\begin{array}{c}\text { SARS-CoV- } \\
23 \mathrm{CL}^{\text {pro }}\end{array}$ & Gold (AuNP) & 470 & 0 \\
\hline $\begin{array}{c}\text { SARS-CoV- } \\
23 \mathrm{CL}^{\text {pro }}\end{array}$ & Eugenol+AuNP & 3332 & -105.83 \\
\hline $\begin{array}{c}\text { SARS-CoV- } \\
23 \mathrm{CL}^{\text {pro }}\end{array}$ & Cholestan-3-ol & 5492 & -234.24 \\
\hline $\begin{array}{c}\text { SARS-CoV- } \\
23 \mathrm{CL}^{\text {pro }}\end{array}$ & Cholestan-3-ol+AuNP & 5448 & -226.35 \\
\hline $\begin{array}{c}\text { SARS-CoV- } \\
23 \mathrm{CL}^{\text {pro }} \\
\end{array}$ & Zinc (ZnNPs) & 470 & 0 \\
\hline
\end{tabular}

Table 2 shows the viral protein and the ligands it was docked with that showed desirable results. The table also depicts the PatchDock Score and the Atomic Contact Energy (ACE).

\section{CONCLUSION}

The current study focused on exploring the anti-viral activity of the major phytochemicals present in the Indian medicinal plants. These medicinal plants were selected due to their common usage in the Indian spices. Thus, there might be a possibility that their natural phytochemicals can provide immunity against the viral infection. These naturally occurring phytochemicals were then conjugated with heavy metal ions such as Iron (Fe), Gold ( $\mathrm{Au})$ and Zinc ( $\mathrm{Zn})$ in order to make their nanoparticle counterpart. The phytochemicals and their nanoparticle conjugates were then docked against the $3 \mathrm{CL}^{\text {pro }}$ sequence of the viral structure to see their interaction. Cys145 and His41 together act as a catalytic dyad in the viral structure. We hypothesized that the phytochemicals and their nanoparticle conjugates might interact with the catalytic dyad of the viral structure and thereby act as a natural inhibitor of the viral infection. The present study demonstrated that the 7 naturally occurring phytochemicals showed the desired binding with the active site of the viral structure and 5 iron nanoparticle conjugate, 2 gold nanoparticle conjugate and 2 zinc nanoparticle conjugates gave the desired results. Although, the present study only focused on the molecular docking aspect of the viral structure and the phytochemicals, this study opens up a new domain to try and synthesize drugs from these medicinal plants using the pharmacophore modelling in order to create natural inhibitors against the virus.

\section{ACKNOWLEDGEMENT}

The authors would like to acknowledge Ms. Sneha Kapse and Mr. Avishek Paul for their valuable feedback and proofreading the manuscript.

\section{REFERENCE}

[1] Ali, M. M., Yusuf, M. A., \& Abdalaziz, M. N. (2017). GCMS Analysis and Antimicrobial Screening of Essential Oil from Lemongrass ( Cymbopogon citratus ). 3(6), 72 76. https://doi.org/10.11648/j.jpp.20170306.11 


\section{International Journal of Engineering Applied Sciences and Technology, 2020 \\ Vol. 5, Issue 6, ISSN No. 2455-2143, Pages 324-330 \\ Published Online October 2020 in IJEAST (http://www.ijeast.com)}

[2] Anand, K., Anand, K., Ziebuhr, J., \& Wadhwani, P. (2003). ( 3CL pro ) Structure: Basis for Design of AntiSARS Drugs.

1763. https://doi.org/10.1126/science. 1085658

[3] Anshory, H., \& Nugraha, A. T. (2017). Gas Chromatography - Mass Spectrometry Analysis and Antibacterial activity of Cinnamomum burmanii Essential Oil to Staphylococcus aureus and Escherichia coli by Gaseous Contact. 020073. https://doi.org/10.1063/1.4978146

[4] Balasubramanian, S., Ganesh, D., Reddy, P. S., \& Narayana, V. V. S. S. (2014). Asian Journal of Pharmaceutical Analysis and Medicinal Chemistry. 2(2), 71-75.

[5] Bar-zeev, N., \& Moss, W. J. (2020). Comment Encouraging results from phase $1 / 2$ COVID-19 vaccine trials. The Lancet, 6736(20), 19-20. https://doi.org/10.1016/S0140-6736(20)31611-1

[6] Bawankar, R., Deepti, V. C., Singh, P., Subashkumar, R., Vivekanandhan, G., \& Babu, S. (2012). Evaluation of Bioactive Potential of an Aloe vera Sterol Extract. (July). 27(6), 864-868. doi:10.1002/ptr.4827

[7] ChemOffice, 7.0.1. 2002. CambridgeSoft, Corporation, Cambridge, MA.

[8] Chen, Y., Liu, Q., \& Guo, D. (2020). Emerging coronaviruses: Genome structure, replication, and pathogenesis. (January), 418-423. https://doi.org/10.1002/jmv.25681

[9] Dhaiwal, K., Kaur, K., Dalvir, C., \& Amit, K. (2017). Gas chromatography-mass spectrometry analysis and in vitro antioxidant potential of ajwain seed ( Trachyspermum ammi L .) essential oil and its extracts. (December 2016), 1-10. https://doi.org/10.1111/jfbc.12364

[10] El-sheekh, M. M., Shabaan, M. T., Hassan, L., \& Hanaa, H. (2020). Antiviral activity of algae biosynthesized silver and gold nanoparticles against Herps Simplex ( HSV-1 ) virus in vitro using cell-line culture technique. International Journal of Environmental Health Research, O0(00), 1-12. https://doi.org/10.1080/09603123.2020.1789946

[11] Folegatti, P. M., Ewer, K. J., Aley, P. K., Angus, B., Becker, S., Belij-rammerstorfer, S., ... Pollard, A. J. (n.d.). Articles Safety and immunogenicity of the ChAdOx1 nCoV-19 vaccine against SARS-CoV-2: a preliminary report of a phase $1 / 2$, single-blind, randomised controlled trial. 1-13. https://doi.org/10.1016/S0140-6736(20)31604-4

[12] Hu, D., Zhu, C., Ai, L., He, T., Wang, Y., Ye, F., ... Wang, C. (2018). Genomic characterization and infectivity of a novel SARS-like coronavirus in Chinese bats. Emerging Microbes \& Infections. https://doi.org/10.1038/s41426-018-0155-5

[13] Ji, W. (2020). Cross - species transmission of the newly identified coronavirus 2019 - nCoV. (January), 433-440. https://doi.org/10.1002/jmv.25682

[14] Kumar, V., Jung, Y., Liang, P., Kumar, V., Jung, Y., \& Liang, P. (2013). Expert Opinion on Therapeutic Patents Anti-SARS coronavirus agents : a patent review ( 2008 - present ) Anti-SARS coronavirus agents : a patent review ( 2008 -- present ). 3776. https://doi.org/10.1517/13543776.2013.823159

[15] Kumaravel, S., Muthukumaran, P., \& Shanmugapriya, K. (2017). Chemical composition of Trigonella foenumgraecum through gas chromatography mass spectrometry analysis. 5(3), 1-3.

[16] Kuo, C., \& Liang, P. (2015). Characterization and Inhibition of the Main Protease of Severe Acute Respiratory Syndrome Coronavirus. (2), 118-132. https://doi.org/10.1002/cben.201400031

[17] Kuppusamy, P., Yusoff, M. M., \& Maniam, G. P. (2016). Biosynthesis of metallic nanoparticles using plant derivatives and their new avenues in pharmacological applications - An updated report. Saudi Pharmaceutical Journal, 24(4), 473-484. https://doi.org/10.1016/j.jsps.2014.11.013

[18] Lurie, N., Medical, H., Sharfstein, J. M., Hopkins, J., \& Goodman, J. L. (2020). The Development of COVID-19 Vaccines Safeguards $\quad$ Needed. https://doi.org/10.1001/jama.2020.8863

[19] Ma, X., Ph, D., Wang, D., Ph, D., Xu, W., Wu, G., .. Ph, D. (2020). A Novel Coronavirus from Patients with Pneumonia in China, 2019. https://doi.org/10.1056/NEJMoa2001017

[20] Madhumita, M., Guha, P., \& Nag, A. (2019). Industrial Crops \& Products Extraction of betel leaves ( Piper betle L .) essential oil and its bio-actives identi fi cation: Process optimization, GC-MS analysis and antimicrobial activity. Industrial Crops \& Products, 138(July), 111578 . https://doi.org/10.1016/j.indcrop.2019.111578 


\section{International Journal of Engineering Applied Sciences and Technology, 2020 \\ Vol. 5, Issue 6, ISSN No. 2455-2143, Pages 324-330 \\ Published Online October 2020 in IJEAST (http://www.ijeast.com)}

[21] Mengoni, T., Peregrina, D. V., Censi, R., Cortese, M., Ricciutelli, M., Maggi, F., \& Di, P. (2015). Natural Product Research: Formerly Natural Product Letters SPME-GC-MS analysis of commercial henna samples ( Lawsonia inermis $L \quad$.). (August). https://doi.org/10.1080/14786419.2015.1055491

[22] Mint, C., Balasubramanian, S., Ganesh, D., Kiran, K. S., Prakash, K. J. M., \& Vvs, S. N. (2016). GC-MS Analysis of phytocomponents in the methanolic Extract of Mentha International Journal of Chemistry and GC-MS Analysis of phytocomponents in the methanolic Extract of Mentha arvensis ( Corn Mint ). (May), 1-5.

[23] Needle, D., Lountos, T., \& Waugh, D. S. (2015). Structures of the Middle East respiratory syndrome coronavirus 3 C-like protease reveal insights into substrate specificity research papers. 4, 1102-1111. https://doi.org/10.1107/S1399004715003521

[24] Negi, P. S., \& Andola, H. (2015). ot e on is on rs Pe fo $r$ $d$ tri al us $n$. (September). https://doi.org/10.2174/2210315505666150908232137

[25] Pande, K. K., Pande, L., Pande, B., Pujari, A., \& Sah, P. (2010). Gas Chromatographic Investigation of Coriandrum sativum L . from. 3(6), 43-47.

[26] Phadke, M., \& Saunik, S. (2020). Rapid response: Use of angiotensin receptor blockers such as Telmisartan, Losartsan in $\mathrm{nCoV}$ Wuhan Corona Virus infectionsNovel mode of treatment. Response to the emerging novel coronavirus outbreak. BMJ 2020, 368, m406. https://doi.org/ 10.1136/bmj.m406

[27] Sharma, V., Kaushik, S., Pandit, P., Dhull, D., Yadav, J. P., \& Kaushik, S. (2019). Green synthesis of silver nanoparticles from medicinal plants and evaluation of their antiviral potential against chikungunya virus. 881891.

[28] Srivastava, A. K., Srivastava, S. K., \& Syamsundar, K. V. (2005). Bud and leaf essential oil composition of Syzygium aromaticum from India and Madagascar. 1(May 2004), 51-53. https://doi.org/10.1002/ffj.1364

[29] Tahir, M., Alqahtani, S. M., Alamri, M. A., \& Chen, L. (2020). Structural basis of SARS-CoV-2 3CL pro and anti-COVID-19 drug discovery from medicinal plants. Journal of Pharmaceutical Analysis, (xxxx), 1-7. https://doi.org/10.1016/j.jpha.2020.03.009

[30] Tao, Z., Tian, J., Pei, Y., Yuan, M., Zhang, Y., \& Dai, F. (2020). A new coronavirus associated with human respiratory disease in China. 579(March). https://doi.org/10.1038/s41586-020-2008-3
[31] Taylor, P., Raina, V. K., Kumar, A., \& Aggarwal, K. K. (2013). Journal of Essential Oil Bearing Plants Essential Oil Composition of Ginger ( Zingiber officinale Roscoe ) Rhizomes from Different Place in India. (January 2015), 37-41. https://doi.org/10.1080/0972060X.2005.10643442

[32] Tennyson, S., Arivoli, S., Tennyson, S., Divya, S., Rani, S., \& Marin, G. (2019). GC-MS analysis of bioactive compounds of Curcuma longa Linnaeus ( Zingiberaceae ) rhizome extract. 8(6), 49-52.

[33] UCSF Chimera--a visualization system for exploratory research and analysis. Pettersen EF, Goddard TD, Huang CC, Couch GS, Greenblatt DM, Meng EC, Ferrin TE. J Comput Chem. 2004 Oct;25(13):1605-12.

[34] Xu, X., \& Chen, P. (2020). Evolution of the novel coronavirus from the ongoing Wuhan outbreak and modeling of its spike protein for risk of human transmission. 30-33. https://doi.org/10.1007/s11427020-1637-5

[35] Zhou, P., Yang, X., Wang, X., Hu, B., Zhang, L., Zhang, W., Si, H., Zhu, Y., Li, B., Huang, C., Chen, H., Chen, J., Luo, Y., Guo, H., Jiang,R., Liu, M., Chen, Y., Shen, X., Wang, X., Zheng, X., Zhao, K., Chen, Q., Deng, F., Liu, L., Yan, B., Zhan, F., Wang, Y., Xiao, G., Shi, Z (2020). Discovery of a novel coronavirus associated with the recent pneumonia outbreak in humans and its potential bat origin. https://doi.org/10.1101/2020.01.22.914952

[36] Zhu, F., Guan, X., Li, Y., Huang, J., Jiang, T., Hou, L., ... Wang, W. (2020). Articles Immunogenicity and safety of a recombinant adenovirus type-5-vectored COVID-19 vaccine in healthy adults aged 18 years or older: a randomised, double-blind, placebo- controlled, phase 2 trial. The Lancet, 6736(20). https://doi.org/10.1016/S0140-6736(20)31605-6 